\title{
Survey of Major Diseases in Mitha Pata variety of Betelvine (Piper betle L.) under Coastal Saline Zone of West Bengal, India
}

\author{
Prabir Kumar Garain ${ }^{1 *}$, Bholanath Mondal ${ }^{2}$, Atit Maji ${ }^{3}$ and Subrata Dutta ${ }^{4}$ \\ ${ }^{1}$ Ramkrishna Ashram Krishi Vigyan Kendra, Nimpith, South 24 Parganas, West Bengal, India \\ ${ }^{2}$ Department of Plant Pathology, Palli-Siksha Bhavana, Visva-Bharati, Sriniketan, India \\ ${ }^{3}$ Krishi Vigyan Kendra, Murshidabad, West Bengal, India \\ ${ }^{4}$ Department of Plant Pathology, Bidhan Chandra Krishi Viswavidyalaya, Mohanpur, India \\ *Corresponding author
}

\section{A B S T R A C T}

Fixed boroj survey was conducted during 2016 \& 2017 in Mitha pata

\section{Keywords}

Disease survey, Betelvine, Collar rot, Leaf rot, Leaf spot, Coastal saline zone, West Bengal

Article Info

Accepted:

20 February 2020

Available Online:

10 March 2020 variety of Betelvine across four Blocks of South 24 Parganas District in the Coastal Saline Zone of West Bengal, India. Among the four diseases surveyed, highest incidence of Sclerotium collar rot (SCR) and maximum severity of Phytophthora leaf rot (PLR), Colletotrichum leaf spot (CLS) and Xanthomonas leaf spot (XLS) was recorded as $17.67 \pm 3.18 \%$, $14.40 \pm 0.46 \%, 6.40 \pm 0.46 \%$ and $9.33 \pm 1.54 \%$, respectively. Kakdwip Block showed consistently higher incidence of SCR (mean incidence $12.00 \pm 0.99 \%$ ), whereas severity of leaf rot and leaf spots were maximum in Namkhana (mean PDI 10.00 \pm 0.71 ) and Patharpratima (mean PDI of CLS $3.55 \pm 0.61 \%$ and XLS $4.67 \pm 0.82 \%$ ), respectively. Where collar rot was mostly confined to the summer months (March to June), the leaf rot and leaf spot diseases were more prevalent in rainy season (July to October.

\section{Introduction}

Betelvine (Piper betle L., Family: Piperaceae) is an important cash crop in West Bengal, where it is cultivated in 19,455 ha area by approximately 5 lakh farm families (Guha and Jain, 1997; Anonymous, 2015). A small boroj of even 10-15 decimals may provide considerable net profit for maintaining a family of five members and can act as a 'household bank', since the leaves can be plucked every week and sold straight in the market as and when liquid cash is required (Jana, 1995).

Out of 100 varieties of this crop cultivated around the world, 40 are found in India and 30 in West Bengal (Guha, 1997). The Coastal 
Saline Zone of West Bengal holds an important position in Betelvine cultivation, sharing $46 \%$ and $49 \%$ of the total area and production, respectively, in the State. This zone, specially the Sagar island in South 24 Parganas District, is also famous for growing Mitha pata variety of Betelvine, which is admired for its fennel-like fragrance, sweet taste and low fibre content, both in national and international market.

In sub-tropical areas, Betelvine is cultivated inside a specially constructed shade house, known as 'boroj', to provide the crop a prerequisite microclimate. But the mild temperature, diffused light, high humidity and moist soil, prevailing inside the boroj, are also congenial for the growth and build up of several pathogens (Sengupta et al., 2011). Among all diseases, the foot rot \& leaf rot (Phytophthora parasitica), leaf spot (Colletotrichum capsici), bacterial leaf spot (Xanthomonas axonopodis pv. betlicola) and collar rot (Sclerotium rolfsii) are the most damaging to this perennial creeper. The Sclerotium collar rot is identified as darkening of collar region of the vine followed by drooping of leaves and gradual wilting of the whole vine and presence of white, ropy mycelia and light to dark brown mustard like sclerotia of the pathogen over the lesion (Chattopadhyay and Maity, 1990).

In Phytophthora leaf rot, circular, black or brownish water soaked spots are observed on leaves, rapidly increasing in size and coalescing to each other leading to rotting of entire leaf (Dastur, 1935). Whereas, in case of Colletotrichum leaf spot, circular to irregular and light to dark brown spots, surrounded by yellow halo, develop on leaves (Maiti, 1977). In case of Xanthomonas leaf spot, brown spots, surrounded by translucent water soaked areas on the lower leaf surface and yellow halo on the corresponding upper surface are found that remain delimited by leaf veins
(Balasubrahmanyam et al., 1994, Bhattacharya et al., 2012). There are reports of 5-90\% crop loss due to foot rot (Dasgupta et al., 2008), 30-100\% loss due to leaf spot and leaf rot (Maity and Sen, 1979) and 2590\% loss due to collar rot disease (Maiti and Sen, 1982).

The present study was taken up to know the seasonality of four diseases in Mitha pata variety of Betelvine in South 24 Parganas District, under the Coastal Saline zone of West Bengal and record their degree of incidence and severity.

\section{Materials and Methods}

\section{Survey of boroj}

'Fixed Boroz Survey' was conducted in four major Betelvine growing Blocks, viz., Sagar Island, Namkhana, Kakdwip \& Patharpratima of South 24 Parganas District, during 2016 and 2017. From each block, 5 villages and from each village, 3 boroz were selected for data collection. The mean of data from the three boroj were considered as village average. Disease incidence and severity were recorded at fortnightly interval, throughout the year. All the selected boroj were of same age (5 year old), where the Mitha pata variety was grown.

\section{Disease rating}

Rating of individual diseases was done by following the below mentioned rating scales:

\section{Disease incidence (\%) of sclerotium collar $\operatorname{rot}(\mathrm{SCR})$}

100 vines were marked randomly in each boroj. Number of infected vines was counted and percentage disease incidence (DI\%) was calculated as, DI $=$ (no. of infected vines) $\mathrm{x}$ 100/ (total vines assessed). 


\section{Disease severity of phytophthora leaf rot (PLR)}

At first, disease rating was done at 0-5 point scale $(0=$ healthy leaf, $1=$ upto $5 \%, 2=6$ $15 \%, 3=16-30 \%, 4=31-50 \%$ and $5=$ above $50 \%$ leaf area covered) with 25 leaves, taken randomly from each boroj, as described by Goswami et al., (1993). Then, Percent Disease Index (PDI) was computed based on the formula as described by Wheeler (1969), viz., $\mathrm{PDI}=$ (sum of all disease rating) $\mathrm{x} 100 /$ (total no. of observation) $\mathrm{x}$ (maximum rating)

\section{Disease severity of colletotrichum leaf spot (CLS)}

At first, the disease rating was done at 0-5 point scale $(0=$ no or a few lesion on leaf, $1=$ upto $10 \%, 2=11-25 \%, 3=26-50 \%, 4=51$ $75 \%$ and $5=$ above $75 \%$ leaf area affected) from 25 leaves, taken randomly from each boroj as described by Goswami et al., (2002). Then, Percent Disease Index (PDI) was computed based on the formula as described by Wheeler (1969).

\section{Disease severity of xanthomonas leaf spot (XLS)}

At first the disease rating was done at 1-3 point scale $(1=1-3$ spots, $2=4-6$ spots and 3 $=$ more than 6 spots) from 25 leaves taken randomly from each replication as described by Tripathi et al., (1984). Then, Percent Disease Index (PDI) was computed based on the formula as described by Wheeler (1969).

The data were subjected to box-plot analysis to get a summarized distribution of disease incidence and severity data, based on minimum, first quartile $\left(25^{\text {th }}\right.$ percentile), median $\left(50^{\text {th }}\right.$ percentile $)$, third quartile $\left(75^{\text {th }}\right.$ percentile) and maximum values of the data.

\section{Results and Discussion}

All the surveyed Blocks showed incidence of the four major diseases under study. However, a considerable variation was observed in seasonality and severity of the diseases across the locations.

\section{Seasonality of betelvine diseases}

Sclerotium Collar Rot (SCR) was found to occur in two distinct seasons during the year (Table 1). The first incidence was detected in the $3^{\text {rd }}$ week of March, which continued to progress and reach its peak infestation during the month of June. There was no fresh infestation of this disease during the rainy months. A second incidence occurred during middle of October, after recession of monsoon and continued to infect the crop upto middle of November, when the temperature started falling. The disease was clearly absent during the rainy and winter months. Several researchers reported that the collar rot pathogen Sclerotium rolfsii survive better at low soil moisture level than at high moisture (Harlapur, 1988; Kulkarni, 2007). However, Maity and Sen (1982) reported that foot rot in betelvine, caused by $S$. rolfsii, was more related to mean minimum temperature $\left(>22^{\circ} \mathrm{C}\right)$ than to rainfall.

Phytophthora Leaf Rot (PLR) \& Xanthomonas Leaf Spot (XLS) were both prevalent during July to October whereas, Colletotrichum Leaf Spot (CLS) was found to occur during July to middle of January. The results corroborated with the findings of other researchers regarding seasonality of incidence of various leaf rot and leaf spot pathogens in Betelvine (Naik et al., 1990; Renubala and Dutta, 1991; Huq, 2011; Chakraborty, 2018). Marimuthu and Rabindran (1988) reported a positive correlation between infestation of Phytophthora spp. in Betelvine and rainfall, from Tamil Nadu. 


\section{Disease incidence and severity}

Village level incidence of Sclerotium Collar Rot (SCR) varied from $6.67 \pm 0.88 \%$ to $17.67 \pm 3.18 \%$ in 2016 and from $5.67 \pm 0.88 \%$ to $15.33 \pm 1.45 \%$ in 2017 (Table 2). According to the pooled data of two year's survey (Fig $1)$, mean disease incidence was highest in Kakdwip Block $(12.00 \pm 0.99 \%)$ and lowest in Sagar $(9.53 \pm 0.81 \%)$. However, the box-plot analysis revealed that both the lowest $25 \%$ and highest $25 \%$ of disease incidence were witnessed in Namkhana Block (Fig 2).

Hence, it can be concluded that the collar rot incidence was consistently in the higher range at Kakdwip Block $(9.50 \pm 2.36 \%$ to $14.17 \pm 1.20 \%$ ) in comparison to the Namkhana Block, where its incidence was highly variable $(6.67 \pm 0.17 \%$ to $16.50 \pm 2.25 \%)$. Similarly, Palakshappa et al., (1986) recorded 35 to $39 \%$ incidence of this disease in Betelvine in Karnataka, whereas
Singh and Chand (1972) and Maiti and Sen (1982) reported 42-62\% loss in Madhya Pradesh and 25-90\% loss in West Bengal, respectively. Phytophthora Leaf Rot was found to be more severe among the leaf rot and leaf spot diseases. Percent Disease index (PDI) of Phytophthora Leaf Rot varied from $1.60 \pm 0.46 \%$ to $14.40 \pm 0.46 \%$ in 2016 and from $1.60 \pm 0.46 \%$ to $9.33 \pm 0.71 \%$ in 2017 (Table 2). The mean PDI (pooled data) was highest in Namkhana Block $(10.00 \pm \% 0.71)$ and lowest in Patharpratima Block (3.23 $\pm 0.54 \%)$. Xanthomonas leaf spot was next to Phytophthora leaf rot in severity during the rainy season whose PDI varied from $0.89 \pm 0.44 \%$ to $9.33 \pm 1.54 \%$ in 2016 and from $1.33 \pm 0.77 \%$ to $5.78 \pm 1.78 \%$ in 2017 . The disease (XLS) was most severe in Patharpratima Block (pooled mean PDI $4.67 \pm 0.82 \%$ ). The severity of Colletotrichum leaf spot varied from $0.53 \pm 0.53 \%$ to $6.40 \pm 0.46 \%$ in 2016 and $1.07 \pm 0.53 \%$ to $4.53 \pm 0.27 \%$ in 2017 .

Table.1 Seasonal incidence of major diseases of Betelvine

\begin{tabular}{|l|c|c|c|c|}
\hline Month & $\begin{array}{c}\text { Sclerotium Collar } \\
\text { Rot (SCR) }\end{array}$ & $\begin{array}{c}\text { Phytophthora } \\
\text { Leaf Rot (PLR) }\end{array}$ & $\begin{array}{c}\text { Colletotrichum } \\
\text { Leaf Spot (CLS) }\end{array}$ & $\begin{array}{c}\text { Xanthomonas } \\
\text { Leaf Spot (XLS) }\end{array}$ \\
\hline January & - & - & + & - \\
\hline February & - & - & - & - \\
\hline March & + & - & - & - \\
\hline April & + & - & - & - \\
\hline May & + & - & - & + \\
\hline June & + & - & - & + \\
\hline July & - & + & + & + \\
\hline August & - & + & + & + \\
\hline September & - & + & + & - \\
\hline October & + & + & + & - \\
\hline November & - & - & + & \\
\hline December & - & - & + & \\
\hline '+' represents presence of visible respective disease symptom and & & \\
\hline- represents absence of visible respective disease symptom &
\end{tabular}


Table.2 Incidence and severity of major diseases of Betelvine in South 24 Parganas district under coastal saline zone of West Bengal

\begin{tabular}{|c|c|c|c|c|c|c|c|c|c|}
\hline \multirow[t]{2}{*}{ Block } & \multirow[t]{2}{*}{ Village } & \multicolumn{2}{|c|}{ DI (\%) of SCR } & \multicolumn{2}{|c|}{ PDI (\%) of PLR } & \multicolumn{2}{|c|}{ PDI (\%) of CLS } & \multicolumn{2}{|c|}{ PDI (\%) of XLS } \\
\hline & & 2016 & 2017 & 2016 & 2017 & 2016 & 2017 & 2016 & 2017 \\
\hline \multirow[t]{5}{*}{ Sagar } & Khansaheb Abad & $9.33 \pm 1.20 *$ & $9.00 \pm 1.00$ & $7.47 \pm 0.71$ & $5.60 \pm 0.92$ & $2.13 \pm 0.53$ & $1.07 \pm 0.53$ & $1.78 \pm 0.44$ & $1.33 \pm 0.77$ \\
\hline & Harinbari & $11.33 \pm 1.67$ & $11.67 \pm 1.20$ & $8.27 \pm 0.96$ & $6.13 \pm 0.71$ & $1.07 \pm 0.71$ & $1.33 \pm 0.71$ & $2.22 \pm 0.89$ & $1.78 \pm 1.18$ \\
\hline & Bamankhali & $9.00 \pm 2.89$ & $8.33 \pm 2.33$ & $9.60 \pm 1.22$ & $7.73 \pm 0.96$ & $1.87 \pm 1.16$ & $1.60 \pm 0.92$ & $1.33 \pm 0.77$ & $2.67 \pm 0.77$ \\
\hline & Rudranagar & $9.67 \pm 1.20$ & $10.33 \pm 1.20$ & $7.73 \pm 1.62$ & $5.87 \pm 1.41$ & $3.47 \pm 0.27$ & $1.87 \pm 0.96$ & $1.78 \pm 0.89$ & $2.22 \pm 1.18$ \\
\hline & Haradhanpur & $8.67 \pm 0.88$ & $8.00 \pm 1.00$ & $6.40 \pm 1.85$ & $5.07 \pm 1.41$ & $1.33 \pm 0.96$ & $1.60 \pm 0.46$ & $3.56 \pm 0.89$ & $3.11 \pm 1.60$ \\
\hline \multirow{5}{*}{ Namkhana } & Debnagar & $6.67 \pm 0.88$ & $7.33 \pm 0.88$ & $10.13 \pm 0.53$ & $8.53 \pm 0.71$ & $0.53 \pm 0.53$ & $1.87 \pm 0.27$ & $2.22 \pm 1.18$ & $4.89 \pm 1.78$ \\
\hline & Madanganj & $9.67 \pm 1.45$ & $9.00 \pm 1.53$ & $10.93 \pm 0.53$ & $9.33 \pm 0.71$ & $4.00 \pm 0.80$ & $2.67 \pm 0.27$ & $5.33 \pm 0.77$ & $3.56 \pm 1.18$ \\
\hline & Namkhana & $17.67 \pm 3.18$ & $15.33 \pm 1.45$ & $14.40 \pm 0.46$ & $8.80 \pm 0.46$ & $1.07 \pm 0.27$ & $2.93 \pm 0.71$ & $4.44 \pm 1.78$ & $3.11 \pm 1.18$ \\
\hline & Shibnagar Abad & $7.67 \pm 0.88$ & $5.67 \pm 0.88$ & $9.60 \pm 1.67$ & $7.73 \pm 1.62$ & $1.60 \pm 0.46$ & $2.13 \pm 1.16$ & $4.89 \pm 1.18$ & $4.00 \pm 2.04$ \\
\hline & Mean & $11.20 \pm 2.09$ & $10.20 \pm 1.85$ & $11.31 \pm 0.84$ & $8.69 \pm 0.28$ & $2.19 \pm 0.71$ & $2.35 \pm 0.20$ & $3.91 \pm 0.62$ & $3.82 \pm 0.30$ \\
\hline \multirow{3}{*}{ Kakdwip } & Gangadharpur & $13.33 \pm 1.20$ & $12.67 \pm 2.03$ & $7.47 \pm 0.96$ & $5.87 \pm 0.96$ & $2.40 \pm 0.46$ & $4.27 \pm 0.96$ & $4.44 \pm 1.18$ & $3.56 \pm 1.18$ \\
\hline & Budhakhali & $9.33 \pm 2.96$ & $9.67 \pm 1.76$ & $10.67 \pm 0.71$ & $8.53 \pm 0.71$ & $2.13 \pm 0.71$ & $2.93 \pm 0.53$ & $0.89 \pm 0.44$ & $2.22 \pm 1.18$ \\
\hline & Mean & $12.33 \pm 0.89$ & $11.67 \pm 0.74$ & $8.91 \pm 0.90$ & $7.63 \pm 0.62$ & $2.88 \pm 0.57$ & $3.57 \pm 0.34$ & $2.84 \pm 0.61$ & $2.49 \pm 0.30$ \\
\hline \multirow[t]{6}{*}{ Patharpratima } & Keorakhali & $13.67 \pm 2.03$ & $10.33 \pm 1.45$ & $3.47 \pm 0.71$ & $2.93 \pm 0.27$ & $3.47 \pm 0.96$ & $3.20 \pm 0.92$ & $4.00 \pm 0.77$ & $3.56 \pm 1.78$ \\
\hline & Dakshin Raipur & $11.33 \pm 0.33$ & $10.67 \pm 2.03$ & $2.67 \pm 0.27$ & $3.20 \pm 0.46$ & $5.07 \pm 0.53$ & $4.00 \pm 1.39$ & $6.67 \pm 0.77$ & $4.44 \pm 1.18$ \\
\hline & Digambarpur & $11.00 \pm 1.53$ & $12.33 \pm 1.45$ & $5.07 \pm 1.62$ & $5.87 \pm 0.96$ & $1.07 \pm 0.53$ & $1.87 \pm 0.71$ & $3.11 \pm 0.44$ & $1.78 \pm 0.44$ \\
\hline & Dakshin Durgapur & $12.67 \pm 1.45$ & $13.00 \pm 1.15$ & $2.40 \pm 0.46$ & $1.60 \pm 0.46$ & $4.80 \pm 0.80$ & $2.40 \pm 0.92$ & $9.33 \pm 1.54$ & $5.78 \pm 1.78$ \\
\hline & Uttar Mahendrapur & $8.67 \pm 0.88$ & $7.00 \pm 1.15$ & $1.60 \pm 0.46$ & $3.47 \pm 0.71$ & $6.40 \pm 0.46$ & $3.20 \pm 0.46$ & $4.44 \pm 0.44$ & $3.56 \pm 0.44$ \\
\hline & Mean & $11.47 \pm 0.85$ & $10.67 \pm 1.04$ & $3.04 \pm 0.59$ & $3.41 \pm 0.69$ & $4.16 \pm 0.90$ & $2.93 \pm 0.37$ & $5.51 \pm 1.12$ & $3.82 \pm 0.65$ \\
\hline
\end{tabular}

* Data represents mean \pm Standard Error 


\section{Pooled data of disease incidence and severity at different blocks}

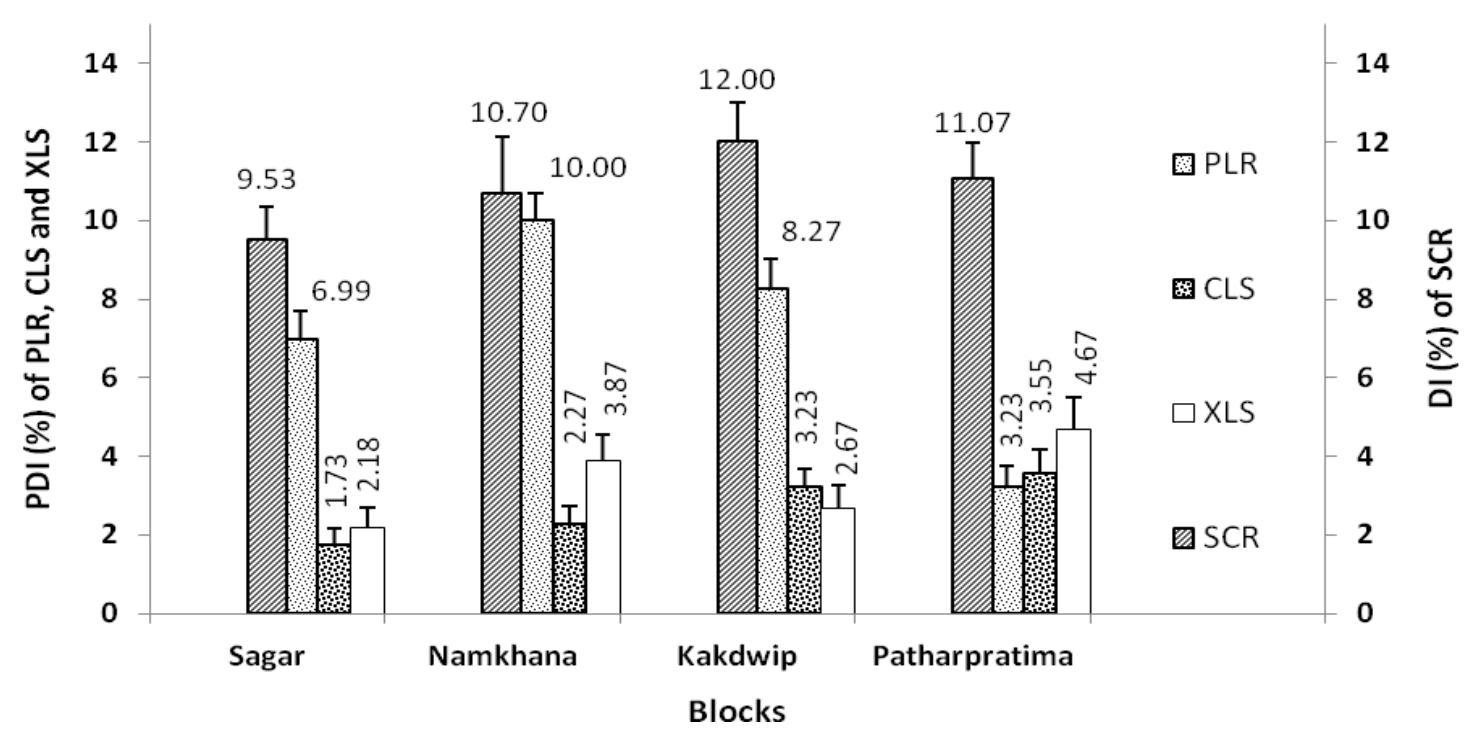

Fig.1 Mean disease incidence (DI) of Sclerotium Collar Rot (SCR) and mean PDI of Phytophthora Leaf Rot (PLR), Colletotrichum Leaf Spot (CLS) and Xanthomonas Leaf Spot (XLS) in four Blocks (pooled data). The error bar represents Standard Error

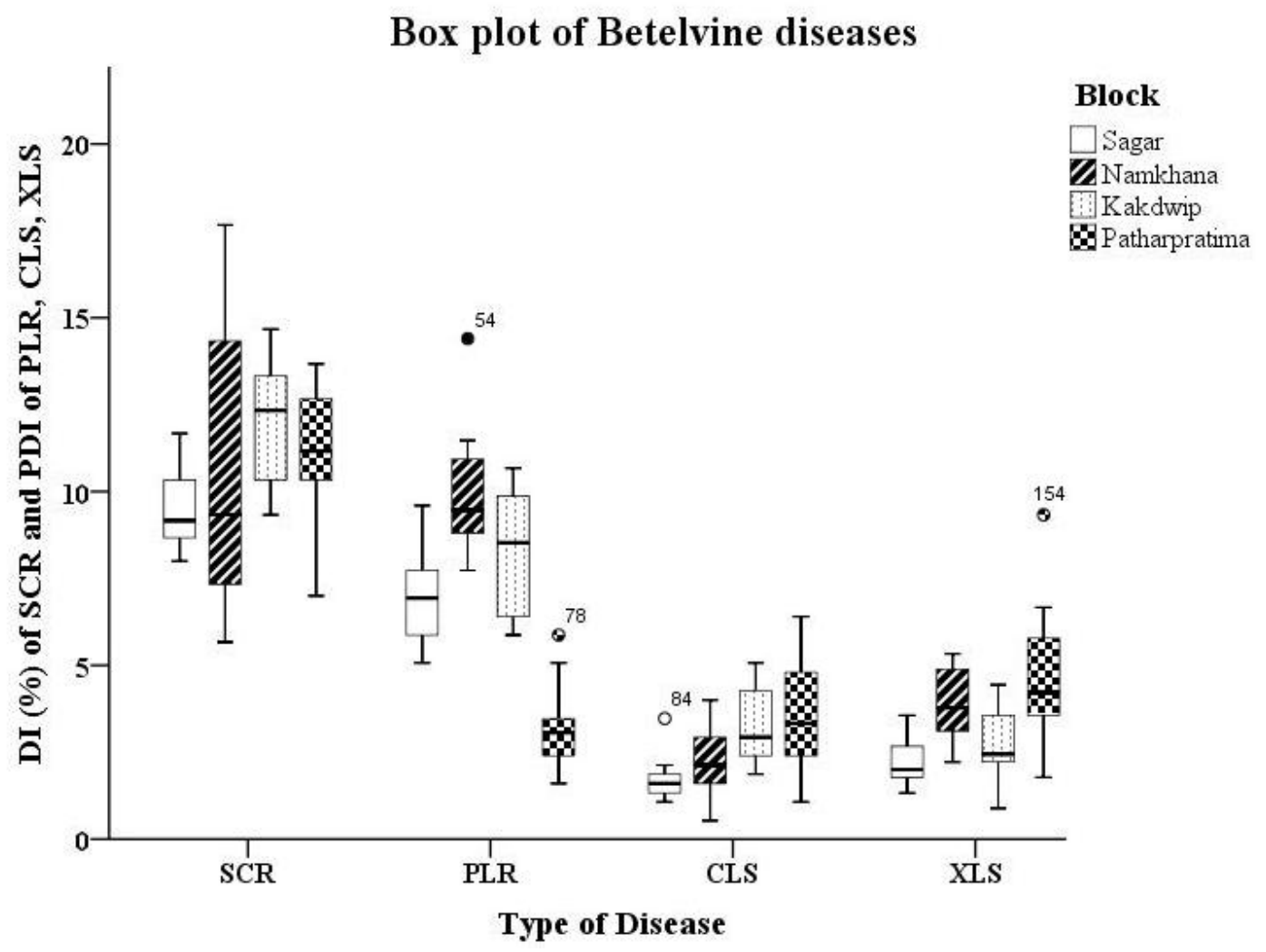

Fig.2 Box-plot, representing the median, quartiles and outliers of disease incidence (DI) of Sclerotium Collar Rot (SCR) and PDI of Phytophthora Leaf Rot (PLR), Colletotrichum Leaf Spot (CLS) and Xanthomonas Leaf Spot (XLS) in four Blocks 
The pooled data shows that the disease was most severe in Patharpratima Block (mean PDI 3.55 $\pm 0.61 \%$ ). Wasnikar and Nayak (1991) reported 4-60\% severity of bacterial leaf spot in betelvine from Madhya Pradesh, whereas, 30-100\% loss was recorded by Maity and Sen (1979) due to leaf spot and leaf rot.

The Mitha pata variety of Betelvine was found to be susceptible to the collar rot during the summer season (March to June) and to leaf rot and leaf spot diseases during the monsoon season (July to October).

The incidence of collar rot (SCR) disease was consistently at higher side in Kakdwip than in other Blocks. Whereas, in case of leaf rot (PLR) and leaf spot diseases (XLS \& CLS), Namkhana and Patharpratima Blocks showed consistently higher severity, respectively.

All the diseases were present at a very low to moderate level in Sagar Block. Though all the surveyed blocks fall under same agroclimatic zone, there may be some differences in local microclimate, variability in pathogen, inoculum level and its perpetuation, agronomic management, plant protection measures and knowledge level among the farmers that might have caused variation in incidence and severity of the four diseases.

These findings may be helpful to construct a location specific disease management module to address different diseases in different season.

\section{Acknowledgement}

The authors wish to express their thanks to the Administration of Ramkrishna Ashram Krishi Vigyan Kendra, Nimpith, for allowing to carry out survey work for the present study. The study is a part of Ph.D. dissertation of the first author who is doing the programme at the Department of Plant Pathology, PalliSiksha Bhavana (Institute of Agriculture), Visva-Bharati.

\section{References}

Anonymous (2015). Chaya Ghore Paan Chas, Directorate of Horticulture, Department of Food Processing Industries and Horticulture, Government of West Bengal, 2014-15.

Balasubrahmanyam, V. R., Johri, J. K., Rawat, A. K. S., Tripathy, R. D. and Chourasia, R. S. (1994). Diseases, pests and their management in Betelvine (Piper betle L.), NBRI, CSIR, Lucknow, pp 88-133.

Bhattacharya, R., Mondal, B., Ray, S. K. and Khatua, D. C. (2012). A study of bacterial disease of betelvine in West Bengal, India. International Journal Journal of Bio-resource and Stress Management, 3(2): 211-216.

Chakrabarty, R. (2018). Effect of environmental factors on diseases of betelvine (Piper betle) in Assam. Indian Phytopathology, 71: 537-542. doi:10.1007/s42360-018-0076-1

Chattopadhyay, S. B. and Maity, S. (1990). Diseases of Betelvine and Spices, Second Edition, Publications and Informations Division, ICAR, New Delhi, pp. 11-13

Dasgupta, B., Mohanty, B., Dutta, P. K., and Maiti, S. (2008). Phytophthora Diseases of Betelvine (Piper betle L.): A Menance to Betelvine crop. SMRC J. Agric., 6: 71-89.

Dastur, J. F. (1935). Diseases of pan (Piper betle) in the Central Provinces. Proc. Indian Acad. Sci., B. 1: 778-815.

Goswami B. K., Zahid M. I. and Haq, M. O. (1993). Screening of Colocasia esculenta germplasm to Phytophthora leaf blight. Bangladesh J. Plant Pathology, 9(1\&2): 21-24.

Goswami, B. K., Kader, K. A., Rahman M. 
L., Islam, M. R. and Malaker, P. K. (2002). Development of leaf spot of betelvine caused by Colletotrichum capsici. Bangladesh J. Plant Pathology, 18(1\&2): 39-42.

Guha, P. (1997). "Paan Theke Kutir Silpa Sambhabana" (In Bengali). "Exploring Betel Leaves for Cottage Industry", pp. 15- 19, In: Krishi, Khadya-O-Gramin Bikash Mela -A Booklet published by the Agricultural and Food Engineering Department, IIT, Kharagpur, India.

Guha, P. and Jain, R. K. (1997). Status Report On Production, Processing and Marketing of Betel Leaf (Piper betle L.). Agricultural and Food Engineering Department, IIT, Kharagpur, India.

Harlapur, S. I. (1988). Studies on some aspects of foot rot of wheat caused by Sclerotium rolfsii Sacc. M. Sc. (Agri.) Thesis, University of Agricultural Sciences, Dharwad.

Huq, M. I. (2011). Studies on the epidemiology of leaf rot and leaf spot diseases of betel vine (Piper betle L.). Bangladesh Journal of Scientific and Industrial Research, 46(4): 519-522

Jana, B. L. (1995). Gram Banglar Arthakari Phasal - Paan (In Bengali). "Betel Leaf: A Cash Crop of Villages of Bengal”. Asaboni, Flat 203, 184, B. B. Chatterji Road, Calcutta.

Kulkarni, V. R. (2007). Epidemiology and Integrated Management of Potato Wilt Caused By Sclerotium rolfsii Sacc, $M$ Sc (Agri) Thesis, Univ. Agric. Sci., Dharwad.

Maiti, S. (1977). Diseases of Piper betle L. with emphasis on the foot rot caused by Sclerotium rolfsii Sacc. and its control. Ph. D. Thesis, Bidhan Chandra Krishi Viswavidyalaya, Kalyani, India, $p p 181$.

Maiti, S. and Sen, C. (1979). Fungal diseases of Betelvine. PANS, 25: 150-57.

Maiti, S. and Sen, C. (1982). Incidence of major diseases of betel vine in relation to weather, Indian Phytopathology, 35(1):14-17

Marimuthu, T. and Rabindran, R. (1988). Influence of weather factors on the incidence of foot rot of betelvine. Indian Phytopathology, 41(3): 373-375.

Naik, M. K., Hiremath,P. C. and Hegde, R. K. (1990). Effect of environmental factors on the incidence of anthracnose of betelvine. Current Research University of Agricultural Sciences Bangalore. 19(10): 174-175

Palakshappa, M. G. (1986). Studies on foot rot of betel vine caused by Sclerotium rolfsii Sacc. in Karnataka. M.Sc.(Agri.) Thesis, University of Agricultural Sciences, Bangalore.

Renubala, K. and Dutta, P. K. (1991). Factors influencing anthracnose disease of betelvine. New Agriculturist, 2(2): 149152

Sengupta, D. K., Dasgupta, A, B. and Datta, P. (2011). Management of foot rot of betel vine (Piper betle L.) caused by Phytophthora parasitica Dastur. Journal of Crop and Weed, 7(2): 179-183.

Singh, B. P. and Chand, J. N. (1972). Assessment of losses of betelvine (Piper betle) caused by Sclerotium rolfsii in Jabalpur (M.P.), Science and Culture, 38 (12): 526-527.

Tripathi, R. D., Johri, J. K. and Balasubrahmanyam, V. R. (1984). Evaluation of chemicals inhibiting the bacterial leaf spot pathogen of betel vine. Tropical Pest Management, 30(4): 440-443.

Wasnikar, A. R. and Nayak, M. L. (1991). Seasonal influence on certain bacterial diseases caused by Xanthomonas campestris pv. betlicola on various betelvine cultivars. Bhartiya Krishi Anusandhan Patrika, 6(2): 91-94

Wheeler, B. E. J. (1969). An introduction to plant diseases. John Wiley and Sons Ltd., London. 


\section{How to cite this article:}

Prabir Kumar Garain, Bholanath Mondal, Atit Maji and Subrata Dutta. 2020. Survey of Major Diseases in Mitha Pata variety of Betelvine (Piper Betle L.) under Coastal Saline Zone of West Bengal, India. Int.J.Curr.Microbiol.App.Sci. 9(03): 2490-2498.

doi: https://doi.org/10.20546/ijcmas.2020.903.285 